\title{
The spatiotemporal distribution of N-CAM in the retinotectal pathway of adult goldfish detected by the monoclonal antibody D3
}

\author{
MARTIN BASTMEYER ${ }^{1}$, BURKHARD SCHLOSSHAUER ${ }^{2}$ and CLAUDIA A. O. STUERMER ${ }^{1, *}$ \\ ${ }^{1}$ Friedrich-Miescher-Laboratorium der Max-Planck-Gesellschaft, Spemannstrasse 37-39, 7400 Tubingen, FRG \\ ${ }^{2}$ Max-Planck-Institut filr Entwicklungsbiologie, Spemannstrasse 35/I, 7400 Tubingen, FRG \\ * Author for correspondence
}

\section{Summary}

The spatiotemporal distribution of neural cell adhesion molecule (N-CAM) in the retinotectal system of adult goldfish was assessed by immunofluorescence using the monoclonal antibody (Mab) D3 against chick N-CAM. In immunoblots with extracts of cell surface membranes of fish brains, Mab D3 recognized a prominent band at $170 \mathrm{~K}$ and a weak band at $130 \mathrm{~K}\left(\mathrm{~K}=10^{3} M_{\mathrm{r}}\right)$. N-CAM immunofluorescence on cells was restricted to the marginal growth zones of the retina and the tectum and, in normal fish, to the youngest axons from the new ganglion cells of the peripheral retinal margin. In fish with previously transected optic nerves (ONS), Mab D3 staining was found transiently on all axons from the site of the cut into the retinorecipient layers of the tectum, but disappeared from these axons 450 days after ONS.
Growing retinal axons in vitro exhibited N-CAM immunofluorescence throughout their entire extent, including their growth cones. Glial cells cultured from regenerating optic nerves were, however, unlabeled.

These data are consistent with the idea that N-CAM is involved in adhesive interactions of growing axons. The temporally regulated expression of N-CAM on the new retinal axons may contribute to the creation of the agerelated organization of the axons in the retinotectal pathway of fish.

Key words: N-CAM, goldfish, regeneration, retinotectal pathway, patterned expression.

\section{Introduction}

During embryogenesis, the formation of intricate tissue structures and their precise interconnection involves many cellular events including cell - cell interaction and recognition. A molecule that plays an important role during the development of the vertebrate nervous system is the neural cell adhesion molecule, N-CAM (Edelman, 1983; Rutishauser, 1984). N-CAM has been shown to be most abundant on developing neuronal and non-neuronal cells and to mediate adhesive interactions via a homophilic binding mechanism between cells, as well as between neurites and their environment. As nerve nets mature and axonal connections stabilize, $\mathrm{N}$ CAM has been shown to undergo changes in amount, and in distribution and structure (Rutishauser, 1986), including loss of polysialic acids that are thought to lead to stabilization of homophilic binding (Schlosshauer $e t$ al. 1984). In warmblooded vertebrates, neurogenesis in the CNS and the establishment of axonal connections are events limited to defined periods of embryonic life. The development of the visual system in fish, however, is different in continuing beyond the period of embryonic development into and throughout adulthood. The retina and the tectum retain proliferative zones which produce neurons throughout adulthood (Johns, 1977; Meyer, 1978; Raymond and Easter, 1983). Thus, groups of retinal axons from newborn ganglion cells may be found in adults to continue to project to their target sites in the tectum (Easter et al. 1981). Another outstanding feature of the fish CNS is the ability of the retinal ganglion cells to regenerate their axons and to re-establish functionally appropriate connections with the tectum (reviewed by Gaze, 1970). The relation between these properties of the fish CNS and the regulation of the expression of molecules that are involved in nerve cell development and axonal growth and regeneration remains to be elucidated. We present here a description of the distribution of N-CAM in the fish visual system. In rodents and birds, N-CAM exists in three forms that vary in the length of their polypeptide chains: N-CAM 180, 140 and 120 (Chuong and Edelmann, 1984). The existence of N-CAM in the fish nervous system has been reported in a study that assessed the evolutionary conservation of the key structures of this molecule: in extracts from adult brains some or all of the characteristic adult form N-CAM polypeptides were present in all species tested (Hoff- 
mann et al. 1984), and these included fish. However, the low molecular weight form of N-CAM may be absent in fish (see Discussion).

Up to now a description of the temporal and regional expression of N-CAM in fish has not to our knowledge been published. Such studies may have been hampered by the fact that a variety of mono- or polyclonal antibodies against mammalian, avian or amphibian $\mathrm{N}$ CAM fails to reveal N-CAM immunoreactivity in sections of fish brains, although some antibodies bind specifically in immunoblots (see Results). An exception is, however, the monoclonal antibody D3, which binds predominantly to the intracellular domain of N-CAM 180 in chick (Schlosshauer, 1989) and recognizes homologues of the chick N-CAM 180 and 140 in fish, as shown in this study. We here describe the spatiotemporal distribution of N-CAM in the retinotectal pathway of normal adult goldfish and in fish with regenerating optic nerves after optic nerve section with immunofluorescence on sections. N-CAM immunofluorescence is found on new cells of the retinal and tectal growth zones, on the new axons from the peripheral retinal ganglion cells and, in fish with previously injured optic nerves, on all regenerating retinal axons. The results have been published in an abstract (Bastmeyer et al. 1989a).

\section{Materials and methods}

\section{Antibodies}

Affinity-purified N-CAM was from embryonic chick retinae (Schlosshauer, 1989). Mab D3, a mouse monoclonal antibody $\left(\mathrm{IgG}_{2 \mathrm{a}}\right)$ raised against purified glycoconjugates of embryonic chick neuronal tissue (Schlosshauer, 1989) was used as a hybridoma supernatant, diluted ascites fluid $(1: 1000)$ or purified immunoglobulin $\left(1-10 \mu \mathrm{g} \mathrm{ml}^{-1}\right)$. Further antibodies, which were kindly provided by colleagues, were five Mabs against chick N-CAM (Pollerberg, unpublished), Mab D1 against chick N-CAM (Schlosshauer, 1989), Mab 2-2B against polysialic acid units (Rougon et al. 1986), Mab 481 against mouse N-CAM 180 (Pollerberg et al. 1985), a rat Mab H-28 against mouse N-CAM (Hirn et al. 1981), a rabbit serum prepared against a synthetic peptide from the $N$-terminal region of N-CAM (Rougon and Marshak, 1986) and rabbit anti-chick N-CAM (Rathjen and Rutishauser, 1984). Secondary antibodies were all from Dianova: horse radish peroxidase-conjugated goat anti-mouse $(\mathrm{IgG}+\mathrm{M})$; FITC-conjugated goat anti-mouse $(\operatorname{IgG}+\mathrm{M})$; RITC-conjugated goat antimouse $(\mathrm{IgG}+\mathrm{M})$; RITC-conjugated goat anti-rat $(\mathrm{IgG}+\mathrm{M})$ and FITC-conjugated goat anti-rabbit $(\operatorname{IgG}+\mathrm{M})$.

\section{Protein analysis}

Cell surface membranes from normal adult goldfish brains or embryonic chick optic tecta were obtained by centrifugation in a sucrose step gradient as described by Walter et al. (1987) and Vielmetter and Stuermer (1989a). Cell surface membrane proteins from goldfish brains were further enriched by homogenizing the membrane fraction in OG buffer ( $10 \mathrm{~mm}$-Tris $\mathrm{HCl}, \mathrm{pH} 7.4,100 \mathrm{~mm}$-octylglycoside, $150 \mathrm{~mm}-\mathrm{NaCl}, 1 \mathrm{~mm}-$ $\mathrm{CaCl}_{2}, 1 \mathrm{~mm}-\mathrm{MgCl}_{2}$, and the following protease inhibitors: $25 \mu \mathrm{g} \mathrm{ml}^{-1}$ Aprotinin, $25 \mu \mathrm{g} \mathrm{ml}^{-1}$ Leupeptin, $5 \mu \mathrm{g} \mathrm{ml}^{-1}$ Pepstatin, and $15 \mu \mathrm{g} \mathrm{ml}^{-1} 2,3$ dehydro-2-deoxy- $N$-acetylneuraminicacid). The lysed membrane proteins were centrifuged at
$150000 \mathrm{~g}$ for $1 \mathrm{~h}$ and the supernatant used for further studies. Protein quantification was performed according to Lowry et al. (1951) and Bradford (1976). SDS - polyacrylamide gel electrophoresis (Laemmli, 1970) and Western blot analysis (Towbin et al. 1979; Hawkes et al. 1982) were performed with slight modifications to identify N-CAM biochemically. Either $2.2 \%$ polyvinylpyrrolidone (1\% PVP-10, $1 \%$ PVP-40 and $0.2 \%$ PVP-200 in TBS: $10 \mathrm{~mm}$-Tris- $\mathrm{HCl} \mathrm{pH} 7,4,100 \mathrm{~mm}-$ $\mathrm{NaCl}$ ) was used for blocking ( $30 \mathrm{~min}$ ) after electroblotting and TBS with $0.1 \%$ Tween 80 and $0.22 \%$ PVP (above relative composition) for washing and antibody incubation, or membrane proteins were run on 5-15\% gradient gels (Laemmli, 1970 ), electroblotted as described, and blocked with $10 \%$ fetal calf serum (FCS) in phosphate-buffered saline (PBS) for $1 \mathrm{~h}$ at room temperature.

\section{Immunohistochemistry on cryostat sections}

The left optic nerves of adult goldfish were cut intraorbitally under MS-222 anaesthesia. After survival times of $13,34,56$, 259 , and 450 days, the eyes, nerves and brains of these fish were dissected in Leibowitz medium (L-15), quickly immersed in Tissue-Tec and frozen in liquid nitrogen. Frozen sections $(10 \mu \mathrm{m})$ were cut on a Reichert-Jung cryostat, collected on polylysine-coated slides, air dried at room temperature for 4 to $5 \mathrm{~h}$ and stored at $-20^{\circ} \mathrm{C}$. Tecta deprived of retinal afferents were obtained from fish the eyes of which had been removed under MS-222 anaesthesia 50 days prior to killing. In addition to adult goldfish, sections were also obtained from goldfish embryos (3 days after fertilization).

Horizontal sections of retinal whole mounts were made from isolated retinae, which were flat-mounted on a nitrocellulose filter. The retina attached to the filter was immersed in Tissue Tec, frozen in liquid nitrogen and cut at $15 \mu \mathrm{m}$ parallel to the filter. Horizontal sections of optic tracts were prepared from isolated nerves, tracts and tecta, mounted on a nitrocellulose filter and sectioned as described.

Sections were fixed and permeabilized in methanol $\left(-20^{\circ} \mathrm{C}\right)$ for $5 \mathrm{~min}$ and rinsed in PBS three times. They were then exposed to Mab D3 (undiluted culture supernatant or ascites fluid, diluted 1:500 in PBS, containing $1 \mathrm{mg} \mathrm{ml}^{-1} \mathrm{BSA}$ ) for $3 \mathrm{~h}$ at $37^{\circ} \mathrm{C}$ and, after three washes in PBS, incubated with FITC- or RITC-coupled goat anti-mouse antibodies $(1: 200$ in PBS containing $1 \mathrm{mg} \mathrm{m}^{-1} \mathrm{BSA}$ ) for $1 \mathrm{~h}$ at $37^{\circ} \mathrm{C}$, washed in PBS and embedded in Elvanol. Photomicrographs were taken using a Zeiss Axiophot with Kodak TMAX 400 films using the appropriate filter sets for RITC and FITC immunofluorescence.

\section{Preparation of retinal explants and glial cells}

Goldfish retinal explants were prepared as described (Vielmetter and Stuermer, 1989a). In brief, eyes were removed from anaesthesized adult goldfish, briefly washed in $96 \%$ ethanol and rinsed in Leibowitz medium (L-15). The retina was isolated and attached (photoreceptor layer down) to a nylon filter (Hybond, Amersham). Filter and retina were cut into $300 \mu \mathrm{m}$-wide segments with a McIlwain Tissue chopper and the segments, ganglion cell layer down, were explanted onto polylysine/laminin-coated coverslips. To keep the retina in contact with the substrate, small metal blocks were placed onto the ends of the filter to which the retina was attached. The cultures were grown in modified L-15 supplemented with $10 \%$ FCS, $4 \%$ methyl cellulose (Dow) and $50 \mu \mathrm{g} \mathrm{ml}^{-1}$ gentamycin (Gibco) at $23^{\circ} \mathrm{C}$ in a humidified chamber for 2 to 3 days. The outgrowing axons were fixed with methanol $\left(-20^{\circ} \mathrm{C}\right)$ for $5 \mathrm{~min}$, rehydrated in PBS and incubated with Mab D3 (undiluted culture supernatant or ascites fluid diluted 1:500 in PBS, containing $1 \mathrm{mg} \mathrm{ml}^{-1}$ BSA) for $30 \mathrm{~min}$. After 
three washes in PBS the cultures were treated with FITC- or RITC-coupled goat anti-mouse antibodies (1:200 in PBS containing $1 \mathrm{mg} \mathrm{ml}^{-1} \mathrm{BSA}$ ) for $30 \mathrm{~min}$.

Goldfish glial cells were obtained from regenerating optic nerves of adult goldfish as described (Bastmeyer et al. 1989b). The cells were fixed and permeabilized with methanol $\left(-20^{\circ} \mathrm{C}, 5 \mathrm{~min}\right)$ and rehydrated in PBS. Double immunostaining was carried out with a polyclonal rabbit serum prepared against goldfish glial fibrillary acidic protein (GFAP; Nona et al. 1989) and ascites fluid of Mab D3. The antibodies, both diluted $1: 500$ in PBS (containing $1 \mathrm{mg} \mathrm{ml}^{-1}$ BSA) were applied simultaneously for $1 \mathrm{~h}$ at $37^{\circ} \mathrm{C}$. The secondary antibodies were FITC-coupled goat anti-rabbit serum and RITCcoupled goat anti-mouse serum applied simultaneously at dilutions of $1: 200$ each in PBS.

\section{Results}

\section{Identification of N-CAM in fish with Mab D3}

On immunoblots with cell surface membrane proteins from normal adult goldfish brains Mab D3 detects a major band at approximately $170 \mathrm{~K}\left(\mathrm{~K}=10^{3} M_{\mathrm{r}}\right)$ and a minor band at approximately $130 \mathrm{~K}$ (Fig. 1, lane c). The $170 \mathrm{~K}$ band appears under both blotting conditions described in Materials and methods, whereas the $130 \mathrm{~K}$ form can only be seen if blocking with PVP (which reduces background staining) is omitted and substituted by FCS (Fig. 1, lane d). Using the latter conditions for immunoblots with cell surface membranes of embryonic

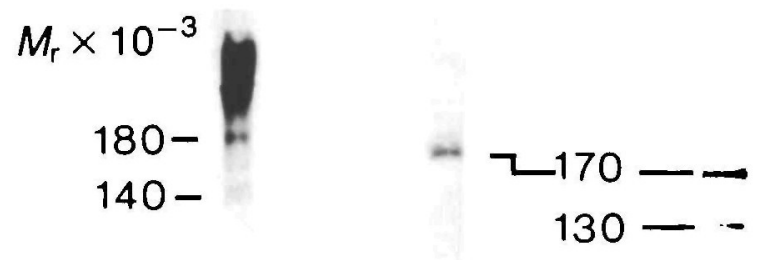

a

b c

Fig. 1. Western blot analysis with cell surface membrane proteins from adult goldfish and embryonic chicken brains enriched by sucrose gradient centrifugation. Samples were subjected to SDS - polyacrylamide gel electrophoresis and subsequent Western blot analysis using monoclonal antibodies against N-CAM. (a) Embryonic chick tectum; (b-d) adult goldfish brain. Mab D3 was used in a, c and d; Mab 2-2B against polysialic acid N-CAM in b. Samples in $a-c$ were run on $10 \%$ gels, and the sample in d on $5-15 \%$ gradient gels. Note that $\mathrm{d}$ reveals protein bands at $130 \mathrm{~K}$ and 170K (see Material and methods). chick brains, Mab D3 also revealed a faint band at $140 \mathrm{~K}$ in chick in addition to the major band at $180 \mathrm{~K}$ and diffuse bands at $250 \mathrm{~K}$ (Fig. 1, lane a), which have been described earlier (Schlosshauer, 1989). The diffuse band at $250 \mathrm{~K}$ indicates the presence of polysialic acids in N-CAM in embryonic chick brains. The absence of these high molecular weight (above $200 \mathrm{~K}$ ) bands in adult fish suggests that the polysialic acid content of $\mathrm{N}$ CAM in adult fish is relatively low. This is consistent with the absence of staining in immunoblots with another monoclonal antibody, Mab 2-2B (Fig. 1, lane b), which is specific for 2-8-linked $N$-acetylneuraminic acid in N-CAM (Rougon et al. 1986). Embryonic goldfish samples have not been analyzed in this study.

Other mono- or polyclonal antibodies against $\mathrm{N}$ CAM in higher vertebrates (listed in Materials and methods) failed to reveal N-CAM on immunoblots or sections of fish brains, so that Mab D3 is the only antibody of those tested that allows the identification of $\mathrm{N}-\mathrm{CAM}$ in goldfish (see Discussion).

\section{Mab D3 immunofluorescence in the normal retinotectal pathway}

In goldfish embryos, immunostaining with Mab D3 is ubiquituous and is seen on the surfaces of all cells and axons in the brain (not shown). In adult fish, however, $\mathrm{N}$-CAM appears to be restricted to well-defined regions as shown by immunofluorescence using Mab D3. Mab D3 binds almost exclusively to regions that are known to harbor newly added cells (Johns, 1977; Raymond and Easter, 1983) and also to the path of the new ganglion cell axons (Easter et al. 1981; Stuermer and Easter, $1984 a$ ). The only exception is the horizontal cell layer of the retina, which fluoresces brightly in fish of all ages.

On horizontal sections through the ganglion cell and the outer fiber layer of flat mounted retinae, Mab D3 exclusively stains cells at the retinal periphery (Fig. 2 A,B). Ganglion cell axons, few in number and coursing superficially from the retinal margin towards the optic disk, are Mab D3-positive (Fig. 2 C,D). The labeled axons leave the eye in the very center of the disk (Fig. 2 E,F) and form a coherent bundle at the ventral edge of the optic nerve (Fig. 3 and Fig. 5). Axons that take these routes are known to originate from the newborn ganglion cells (Easter et al. 1981, 1984; Bunt, 1982). As they approach the tectum the youngest axons acquire a superficial dorsal position in the optic tract (Fig. $3 \mathrm{C}$ ), split to course through the ventral and dorsal brachia and travel along the peripheral margins of the tectum (Stuermer and Easter, 1984a). Only bundles of the retinal axons that are restricted to these positions are Mab D3-positive. Fig. 3 shows a horizontal section through the optic tract, with Mab D3-stained axons acquiring a superficial position as they approach the brachia of the optic tract.

Accretion of new cells in the tectum is restricted to a zone abutting the dorsomedial, ventrolateral and caudal tectal periphery (Raymond and Easter, 1983). Mab D3-positive cells are found exclusively in these regions. The tectal growth zone is asymmetrical, and extends dorsomedially further rostrally than ventrolaterally 

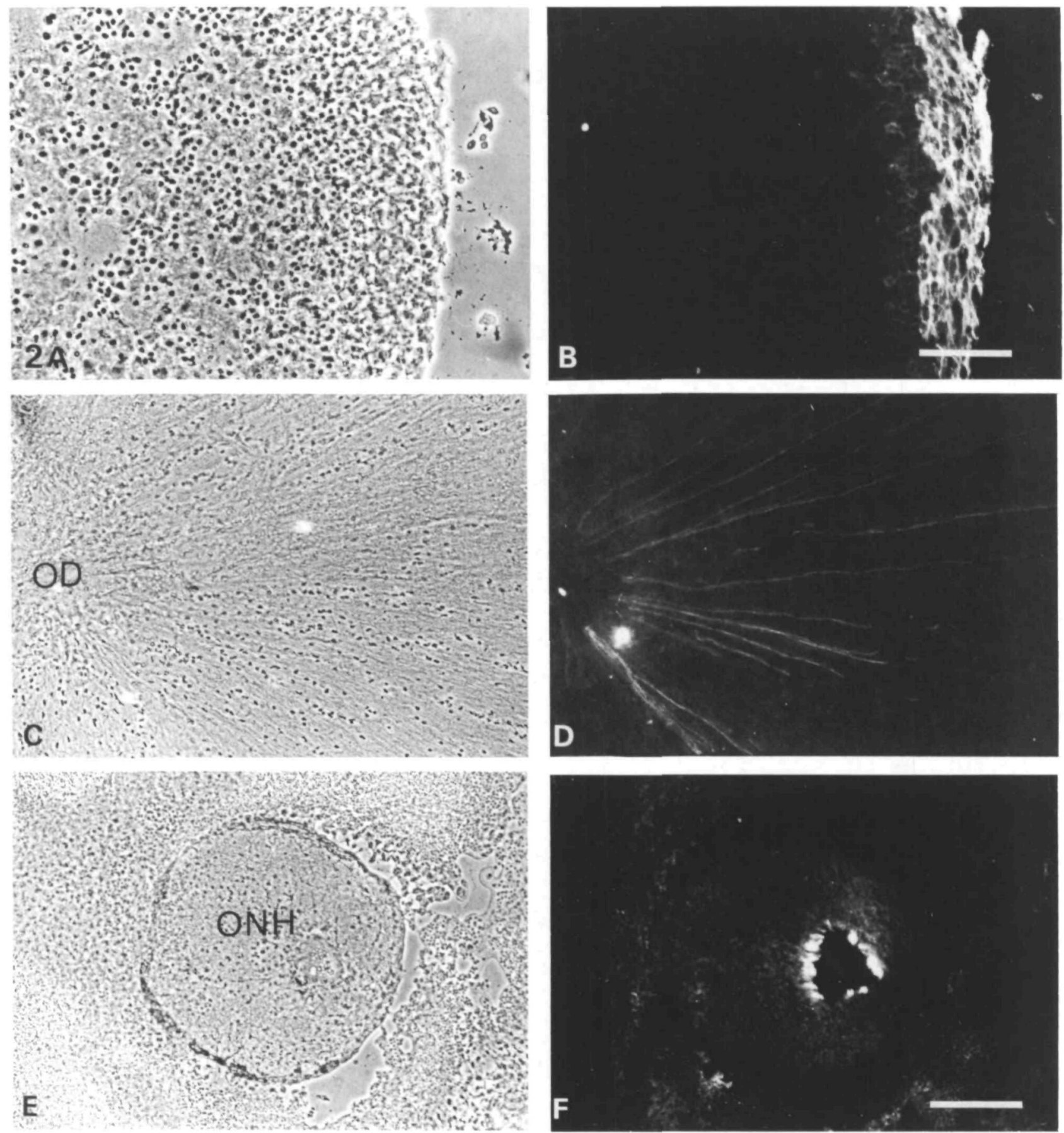

Fig. 2. Horizontal sections through a flat-mounted retina at a superficial and two deeper layers. Corresponding phase contrast (A, C and E) and fluorescence (B, D and F) micrographs. Mab D3 stains cells in the marginal growth zone (A, B) and in the optic fiber layer, only a few axons (C, D). These axons run superficially, converge at the optic disc (od), and leave the eye in the center of the optic nerve head (onh) (E, F). Calibration bar in B for A and B $50 \mu \mathrm{m}$. Calibration bar in $\mathrm{F}, 100 \mu \mathrm{m}$ (applies to $\mathrm{C}-\mathrm{F}$ ).

(Raymond and Easter, 1983) and so is the extension of the band of Mab D3-labeled cells. The lateral edge of a cross section through the caudal half of the tectum is depicted in Fig. 4. As in the rostral tectum (not shown) Mab D3-labeled axons sit at the peripheral-most corner of the retinorecipient layers SO (stratum opticum) and SFGS (stratum fibrosum et griseum super ficiale). In the caudal tectum (but not in the rostral tectum), they run in proximity to Mab D3-positive cells of the tectal growth zone.

Thus, according to the notion that the antibody Mab D3 recognizes N-CAM 180 (Schlosshauer, 1989) and possibly N-CAM 140, these results suggest that the fish homologues of these forms of N-CAM are expressed by cells in the retinal and tectal growth zones and by the youngest retinal axons. 
Mab D3 immunofluorescence in the regenerating retinotectal pathway

When the optic nerve is sectioned (ONS) intraorbitrally, the retinal axons regenerate from the stump connected to the eye, travel along the optic nerve and tract, and enter rostrally into the tectum around 10 to 13 days after ONS. The axons progress through the tectum from rostral to the caudal end and reoccupy the retinorecipient layers SO and SFGS completely
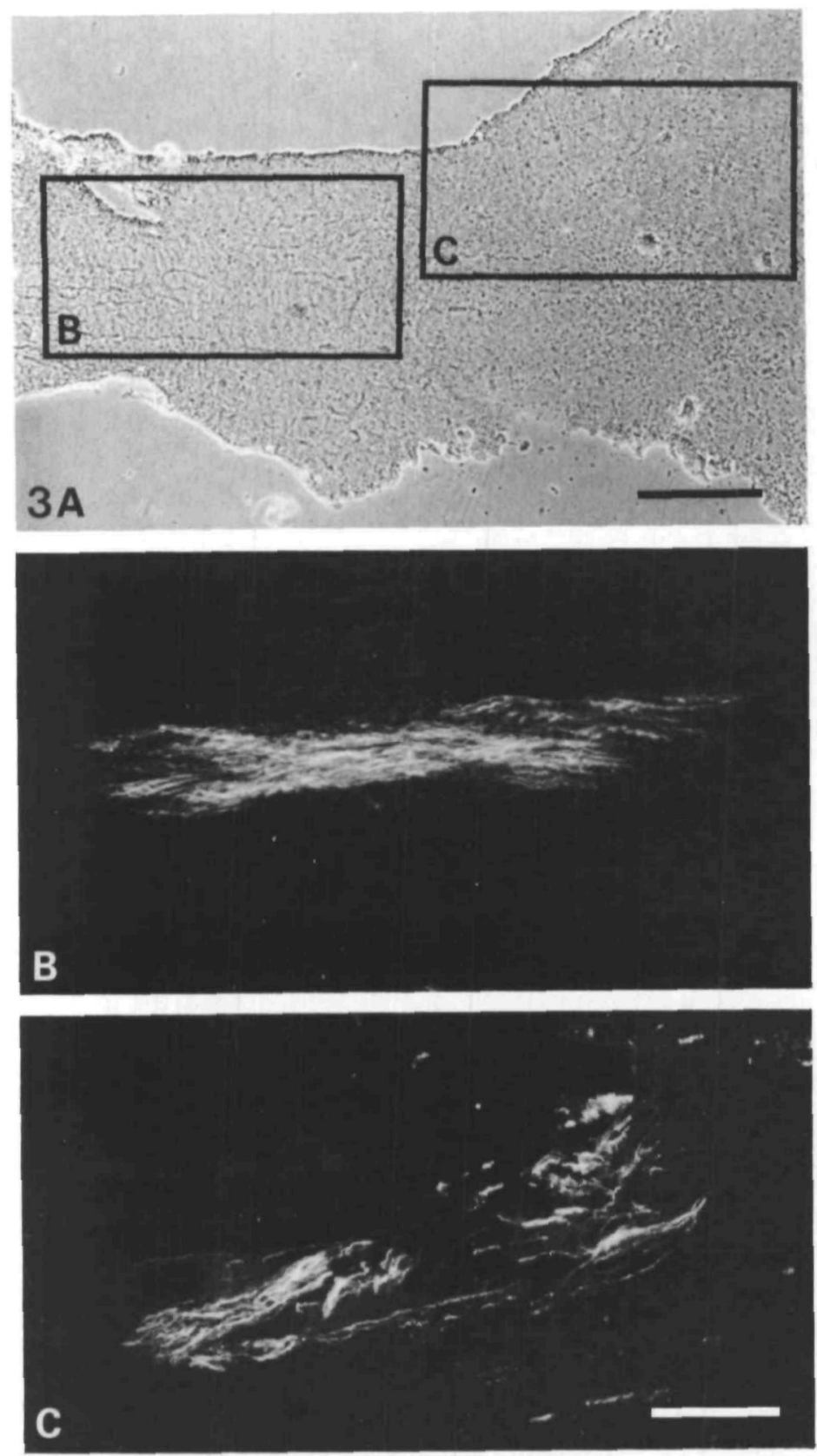

Fig. 3. Horizontal sections of the optic tract. Near the chiasm, Mab D3-positive axons are tightly clustered (B), but run as a sheet in a superficial dorsal position as they approach the brachia of the optic tract (C). (A) Phase contrast of the optic tract. Framed fields represent areas that are shown in B and C. Calibration bar in A $200 \mu \mathrm{m}$. Calibration bar in C, for B and C, $100 \mu \mathrm{m}$.
(Stuermer and Easter, 1984b). The spatial and temporal distribution of Mab D3-labeled processes in the regenerating retinotectal pathway parallels the distribution of the regenerating retinal axons. At both 13 and 34 days after ONS, the regenerating part of the optic nerve
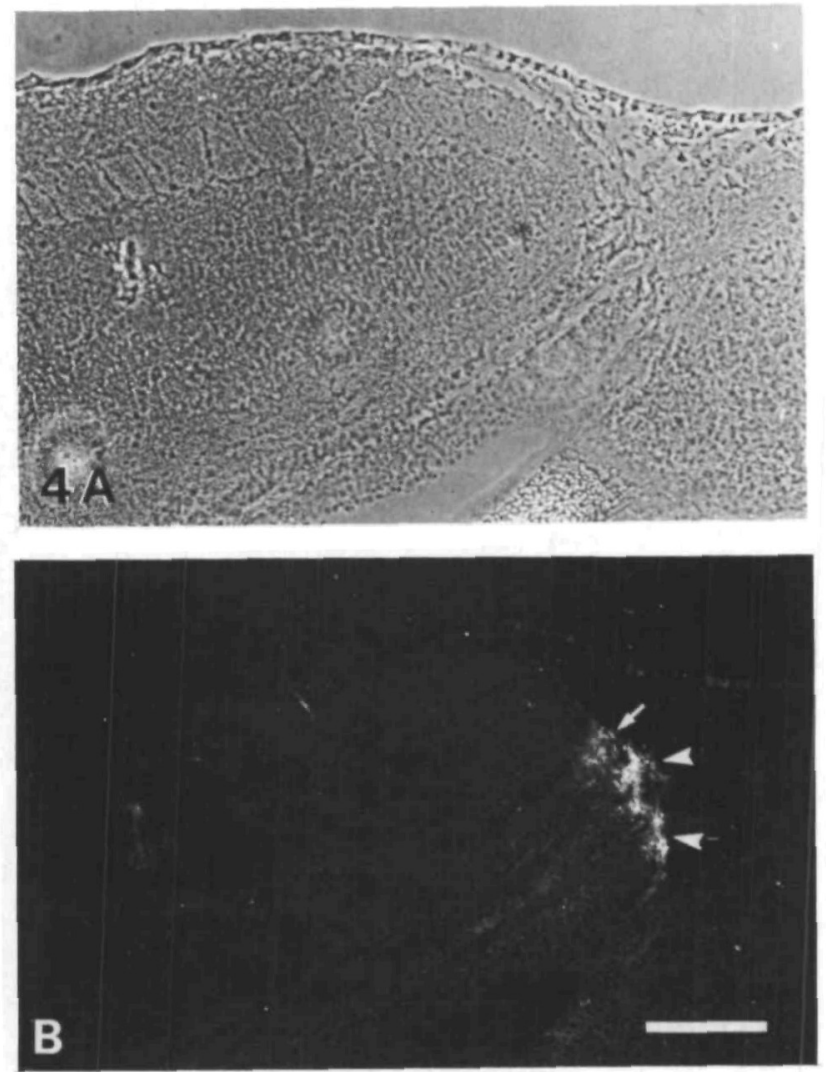

Fig. 4. Transverse section throught the tectum including the marginal growth zone at the dorsomedial edge. (A) Phase contrast. (B) Mab D3 staining is confined to cells (arrowheads) and the group of new axons (arrow). Calibration bar in B for A and B, $100 \mu \mathrm{m}$.

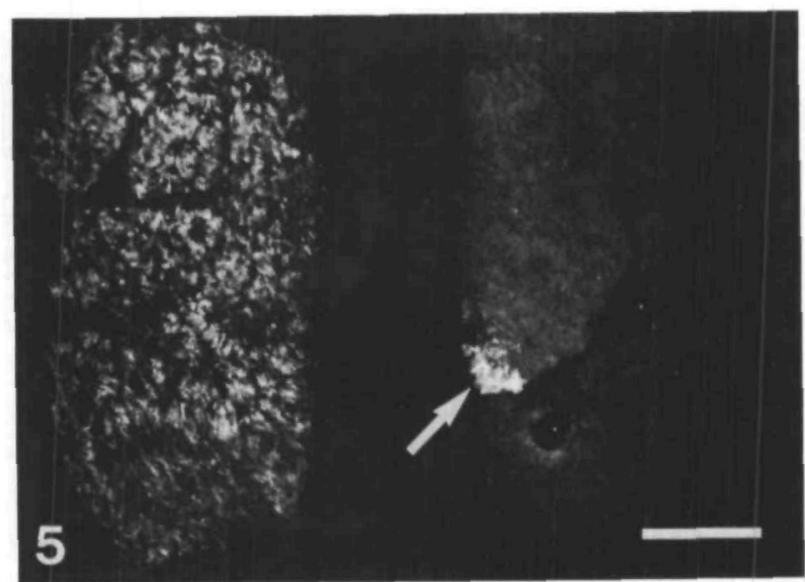

Fig. 5. Transverse section of a normal (right) and a regenerating (left) optic nerve. In the normal optic nerve only the group of new axons (arrow) at the ventral edge is Mab D3-positive. In the regenerating optic nerve (34 days after optic nerve section) all axons apparently express the antigen recognized by Mab D3. Calibration bar, $100 \mu \mathrm{m}$. 

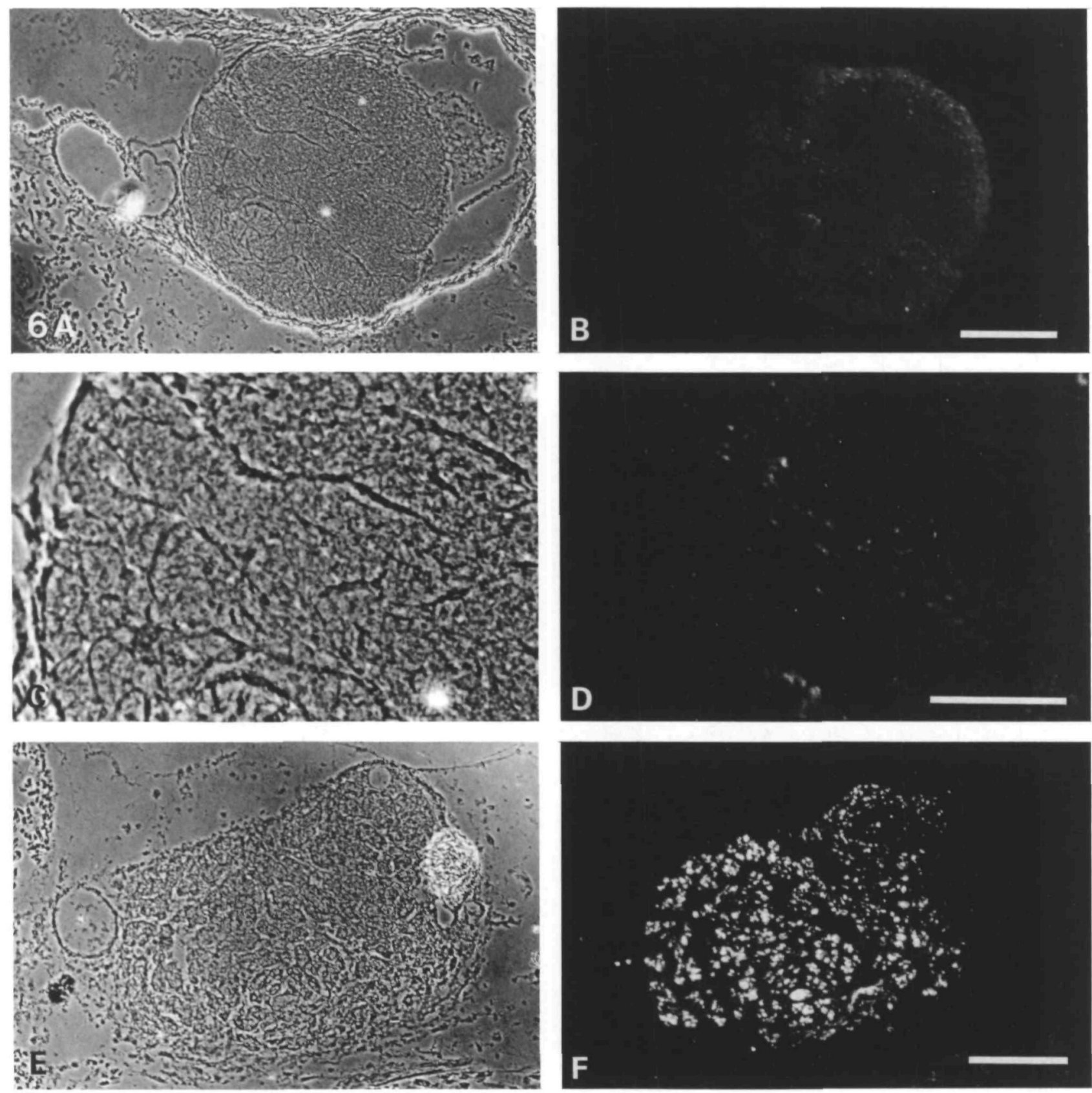

Fig. 6. Sections through one optic nerve 13 days after optic nerve section. $(A, B, C, D)$ Between the retina and the site of section, and $(E, F)$, between the site of section and the tectum. Corresponding phase contrast (A, C, E) and immunofluorescence micrographs $(B, D, F)$. Mab D3 stains axons over the entire cross section in the regenerating part of the nerve (F), but staining is sparse in the nerve stump connected to the eye (B, D). (D) Shows staining at higher magnification than in B. Calibration bars $100 \mu \mathrm{m}$.

exhibits Mab D3-labeled processes over the entire cross section (Figs. 5, 6 E,F). The nerve stump connected to the eye, however, has fewer labeled processes, mostly at its edge where the axons from the newborn ganglion cells are situated (Fig. 6 A,B,C,D). In addition, and not seen in normal optic nerves, are Mab D3-labeled processes that are scattered among unlabeled axons. They may represent branches which, as a response to nerve injury, sprout from the unlesioned segment of the axon. We did not find indications of N-CAM immunoreactivity on glial cells or their processes.

In cross-sections through tecta at 13 days after ONS, a few labeled fibers appear in the retinorecipient layers SO and SFGS, most of them rostrally, fewer in midtectum and hardly any at caudal section levels. At 34 and 56 days after ONS, the retinorecipient layers in the entire tectum exhibit Mab D3-labeled processes in high density. This is exemplified in Fig. 7B by a section at a 

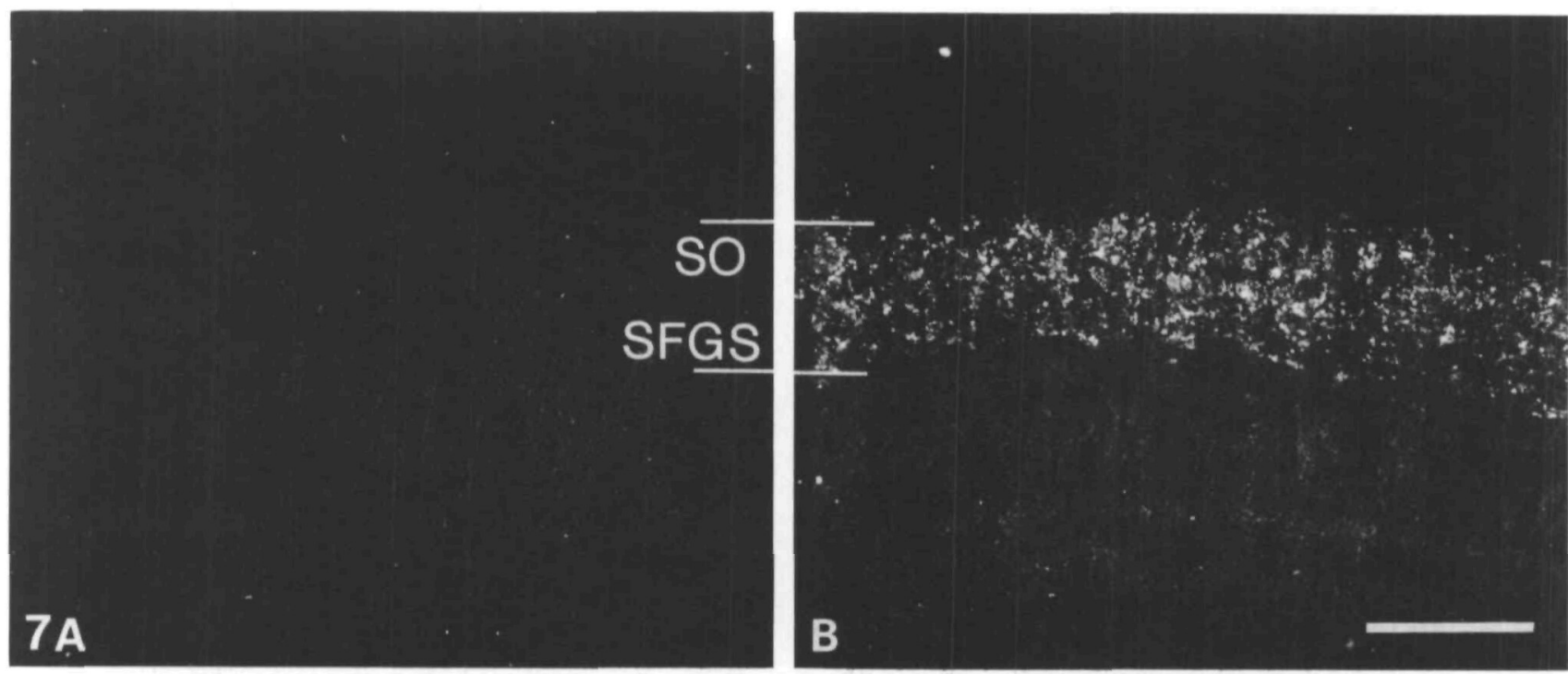

Fig. 7. Transverse sections through the left and right tectum innervated by $A$ normal axons and $B$ by regenerating axons 50 days after left optic nerve section. Mab D3 staining is present on the regenerating axons (B) throughout the retinorecipient layers SO and SFGS, but not on normal axons (A). The white bars in A indicate the extent of SO and SFGS representative for all panels. Calibration bar in B for A and B, $100 \mu \mathrm{m}$.

midtectal level. A section at a comparable level of the contralateral tectum connected to an uninjured optic nerve is devoid of Mab D3-stained processes (Fig. 7A).

The Mab D3 positivity on processes in the retinorecipient layers of the tectum changes with time after ONS. Mab D3 immunostaining on cross-sections at midtectal levels through tecta at 13 (Fig. 8A), 34 (Fig. 8B), 259 (Fig. 8C) and 450 days (Fig. 8D) after ONS documents this finding. While Mab D3 staining is sparse at 13 days, it increased by 34 days, appeared weaker at 259 days, and had disappeared from the retinorecipient layers by 450 days after ONS.

The correlation between the known spatiotemporal distribution of regenerating retinal axons and the appearance of Mab D3-labeling after ONS suggests that Mab D3 binds to the regenerating axons and not to processes of tectal cells or glial cells in the nerve. This inference was confirmed. A tectum that had been deprived of retinal afferents for 4 weeks by enucleation of the contralateral eye was devoid of Mab D3-labeled processes in SO and SFGS, and only showed Mab D3positive cells at the marginal growth zones (not shown).

After explantation of the retina onto growth-permissive substrates such as laminin, the ganglion cells emit new axons (Johns et al. 1978; Vielmetter and Stuermer, 1989a). After fixation and exposure to Mab D3, the axons emerging from the retinal explants were brightly stained (Fig. 9), providing further evidence that $\mathrm{Mab}$ D3 recognizes growing retinal axons. Staining reached into the growth cones and included the proximal portions of the filopodia (Fig. 9C).

In contrast to regenerating axons, glial cells cultured from regenerating optic nerves and tracts (Bastmeyer et al. 1989b) did not exhibit any Mab D3 positivity (Fig. 10), a finding that correlates with the absence of staining on processes other than the axons in sections of the optic nerve and tract.

Taken together, these results indicate that regenerating retinal axons reacquire the antigens that are recognized by the Mab D3. The expression of Mab D3positive sites on regenerating axons is temporally regulated and gradually decreases until it finally ceases to be detectable.

\section{Discussion}

\section{Molecular identity of the Mab D3-antigen}

This study describes the spatiotemporal distribution of $\mathrm{N}$-CAM in the retinotectal system of goldfish using the monoclonal antibody D3. Mab D3 is specific for the intracellular part of chick N-CAM, and stains predominantly N-CAM 180 from chick brain membranes on Western blots (Schlosshauer, 1989). Only when the gel was loaded with affinity-purified N-CAM was a minor band at $140 \mathrm{~K}$ visible, leading to the speculation that Mab D3 may bind to a region of the N-CAM polypeptide chain that is in part shared by N-CAM 140 and 180 (Cunningham et al. 1987). Consistent with this assumption is the fact that Mab D3 recognizes bands at $170 \mathrm{~K}$ and $130 \mathrm{~K}$ on immunoblots of fish brain extracts. These are most likely the fish homologues of the chick $\mathrm{N}$ CAM 180 and 140.

We would have liked to have been able to substantiate that Mab D3 is indeed specific for N-CAM in fish, and therefore we tested a variety of mono-and polyclonal antibodies against chicken or mouse N-CAM (see Material and methods), but none stained fish brain sections or revealed specific bands on immunoblots. That most antibodies against rodent or chick N-CAM (or other antibodies against molecules of the nervous 

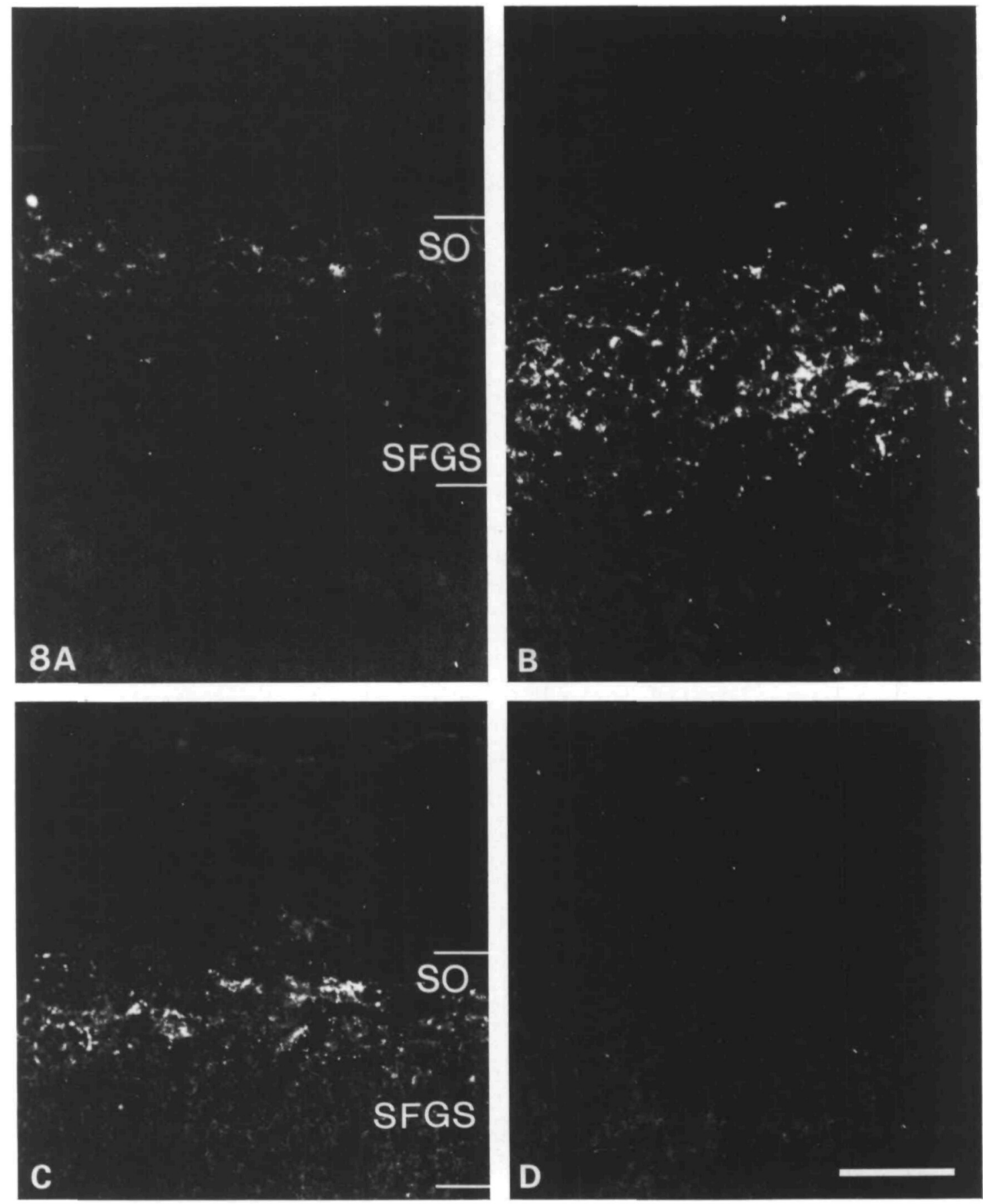

Fig. 8. Sagittal (A) and transverse sections (B, C and D) through midtectal regions of tecta at different times after optic nerve section (ONS). Mab D3 staining is sparse at 13 days after ONS (A), has increased at 34 days (B), appears weaker at 259 days (C) and has disappeared at 450 days (D) from the retinorecipient layers. The white bars in $A$ and $C$ indicate the extent of SO and SFGS representative for all panels. Calibration bar in D, $50 \mu \mathrm{m}$ (applies to all panels).

system) fail to crossreact with fish has been noted previously (see e.g. Sharma et al. 1988; Nona et al. 1989). There are, however, good reasons to believe that Mab D3 does detect N-CAM in fish. First, the histological staining pattern revealed by Mab D3 in adult fish is distinct and resembles closely the spatial distribution of N-CAM immunoreactivity in Xenopus larvae assessed by a polyclonal anti-Xenopus N-CAM (Jacobson, 1988). Second, Mab D3 stains distinct bands on West- ern blots close to the expected molecular weights for $\mathrm{N}$ CAM from a variety of species including mouse, chick and frog (Hoffman et al. 1984): immunoblots from lower vertebrates such as shark, newt and salamander showed a prominent band at $180 \mathrm{~K}$ and a weaker one at $140 \mathrm{~K}$. A band that would indicate the existence of $\mathrm{N}$ CAM 120 was not apparent on immunoblots of lower vertebrates, suggesting that a low molecular weight form of N-CAM is absent in these vertebrates, or 

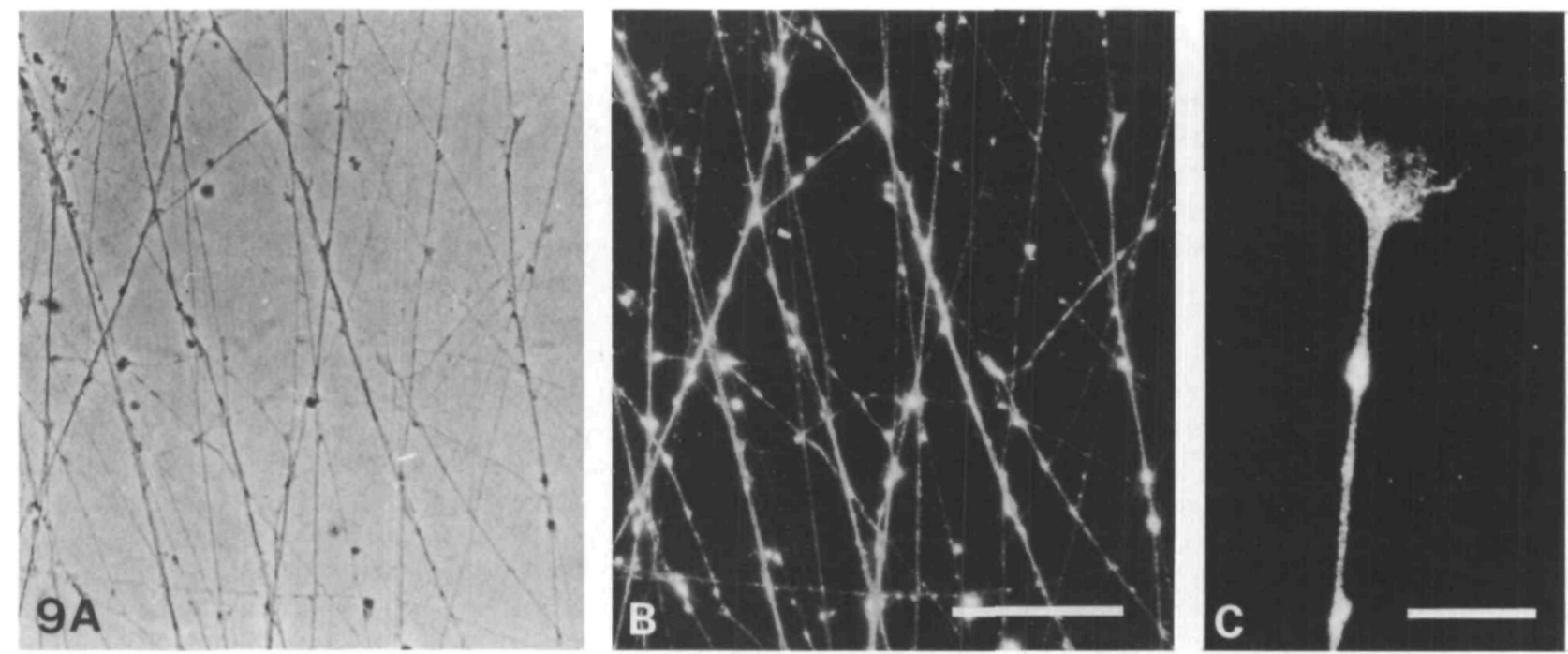

Fig. 9. Goldfish retinal axons growing in vitro. Corresponding phase contrast (A) and immunofluorescence (B) micrographs. Almost all axons are stained with Mab D3 over their entire extent including their growth cones (C). Calibration bar in B for $A$ and $B, 50 \mu \mathrm{m}$, and in $\mathrm{C}, 10 \mu \mathrm{m}$.
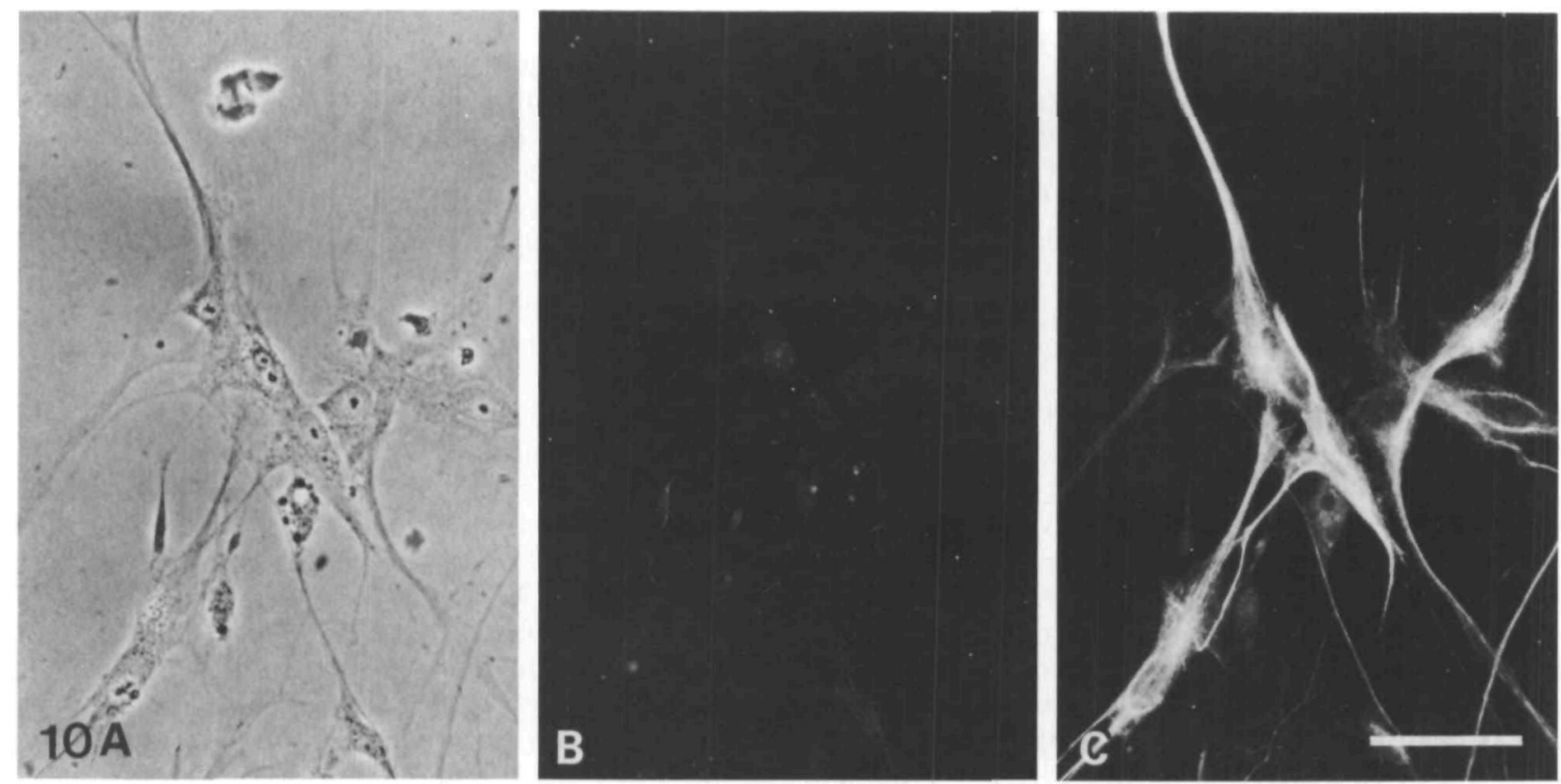

Fig. 10. Glial cells from regenerating goldfish optic tracts growing in vitro. (A) Phase contrast (B, C). Double immunofluorescence with Mab D3 (B) and polyclonal antiserum against GFAP (C). (B) All cells, including GFAP positive glial cells (C) are N-CAM-negative. Calibration bar in C for A-C, $50 \mu \mathrm{m}$.

present only in traces (Hoffman et al. 1984). That $\mathrm{N}-$ CAM 180 is the predominant form of the neural cell adhesion molecule and that N-CAM 140 is present only in low amounts in amphibians is confirmed by other publications (Jacobson and Rutishauser, 1986; Sunshine et al. 1987; Fraser et al. 1988). It may be assumed therefore that teleosts resemble amphibians and cartilaginous fish in expressing N-CAM 180 and N-CAM 140, but not N-CAM 120. Thus, Mab D3-detected immunoreactivity may be represent fish $\mathrm{N}-\mathrm{CAM}$.

\section{N-CAM involved in the age-related organization of} retinal axons

High levels of N-CAM were found in fish embryos, as in other vertebrate embryos (Rutishauser, 1984), on the surfaces of all nerve cells and their axons. In adult fish, the level of N-CAM on most neurons and axons had fallen to such an extent that it was no longer detectable by Mab D3-N-CAM immunofluorescence. The exception was zones that retain embryonic properties: the annular growth zone in the periphery of the retina and 
the half-moon-shaped zone abutting the caudal tectal end (Raymond and Easter, 1983). In addition to these cells, the axons emerging from the new ganglion cells in the retina exhibited high levels of N-CAM throughout their entire course through the retina, the nerve, tract and tectum. Since the routes taken by the new axons have been documented in detail (Easter et al. 1981; Stuermer and Easter, 1984a; Easter et al. 1984; Bunt, 1982), the position of the labeled profiles in crosssections of the nerve, tract and tectum identified them as young axons.

The new axons are of small diameter and are unmyelinated (Easter et al. 1984). They travel superficially in apposition to slightly larger (i.e. older) and still unmyelinated axons (Easter et al. 1984). Our present finding that these young axons carry high levels of N-CAM on their surfaces indicates that N-CAM-mediated adhesion is involved in young axon-young axon association. Since high level N-CAM expression is confined to the young axons, is transient, and is lost with further maturation, N-CAM could function as a guidance cue for the growth cones of the most recent axons. In other words, the unique spatiotemporal distribution of $\mathrm{N}$ CAM in adult fish could determine the path for the new axons.

An antigen that is different from N-CAM but is found in a similar spatiotemporal distibution to N-CAM is recognized by the antibody E587 (Vielmetter and Stuermer, 1989b) indicating that N-CAM is not the only molecule that is present in high concentrations on the growing axons in fish, and suggesting that E587 may, in addition to N-CAM, promote selective fasciculation of the young axons. Other molecules fulfilling such functions are L1 (Rathjen and Schachner, 1984), F11 and neurofascin (Rathjen et al. 1987) of the chick and mouse, but these have not yet been identified in fish. The development of the age-related organization of retinal axons in the retinotectal pathway of fish could therefore result from the spatiotemporal pattern in which N-CAM and molecules with related properties are expressed on the axons. Another indication for the importance of the patterned expression of N-CAM for the selective fasciculation of the fish retinal axons and the creation of the age-related order in the optic nerve is the finding that regenerating axons do not restore this order (Stuermer and Easter, 1984b; Stuermer, 1986). All axons express N-CAM simultaneously on their regenerating portion, and (consequently) the axons fasciculate with each other at random.

In the normal optic nerve, axons not only become ordered by age (their radial retinal origin), but also by their origin from retinal sectors (Bunt, 1982; Easter et al. 1981). Dorsal axons form bundles distinct from bundles of ventral axons, and nasal axons are separate from temporal axons. Some sorting of axons according to their sectorial retinal origin (though incomplete) is also observed during optic nerve regeneration (Bernhardt and Easter, 1988). Despite the absence of an agerelated organization, regenerating axons restore a retinotopic map of near normal precision (Schmidt et al. 1983; Meyer et al. 1985; Rankin and Cook, 1986;
Stuermer, 1988a). Thus, recognition molecules or spatial markers must exist in the retinotectal system that encode position, independent of a spatiotemporal regulation of their expression.

\section{N-CAM on regenerating axons}

For most axons, the re-expression of high levels of $\mathrm{N}$ CAM after optic nerve injury is restricted to the regenerating portion. Elevated levels of N-CAM, which would allow detection by immunofluorescence, were not seen on the ganglion cells or on the old portion of the axons, with a few exceptions. The few labeled profiles in the surviving part of the nerve could represent axonal sprouts emerging by back-branching after optic nerve injury. Alternatively, some axons might die back further than the greater majority and regenerate from the cell body or from segments closer to the cell body. The cells must therefore be capable of confining $\mathrm{N}$-CAM molecules to specific parts of their processes. This confinement of N-CAM may be achieved by a linkage of the molecule to the cytoskeleton. N-CAM 180 has a membrane spanning domain with which such links might be established (Pollerberg et al. 1987). The antigen recognized by the monoclonal antibody E587 in goldfish that is, like N-CAM, specific for growing axons in fish (Vielmetter and Stuermer, 1989b) shows the same lesion-induced re-expression on the regenerating portion of the axons. In their restriction to defined parts of the axon, the distribution of N-CAM resembles to the patterned distribution of Tag 1 and $\mathrm{L} 1$ on the commissural axons of the rat spinal cord (Dodd et al. 1988). Another example is the patterned expression of the fasciclins on axons in developing grasshopper and Drosophila (Harrelson and Goodman, 1988).

The expression of N-CAM on the axons from newborn ganglion cells and on the regenerating portions of axons from older ganglion cells diminishes with time. It is not known whether this decline obeys a temporal rule, or whether environmental cues are the effectors. For developing Xenopus it has been reported that the formation of synaptic connections with the target is the trigger for N-CAM downregulation (Jacobson, 1988). At present we do not have any conclusive evidence for a causal relation between synapse formation and N-CAM downregulation in fish. The time course of outgrowth and synaptogenesis for the new axons from the retinal annular growth zone is not known. For regenerating axons, the process of tectal re-innervation is complex. When the first regenerating axons have reached the tectum at 10-14 days after optic nerve section, they rapidly form synapses in the rostral tectum (Stuermer and Easter, 1984b). The number of axons arriving in the tectum increases up to 30 days and they progress from the rostral to the caudal tectum. The formation of synapses parallels this progression (Stuermer and Easter, 1984b). Since N-CAM immunofluorescence is still at its peak 56 days after optic nerve section, this initial phase of synapse formation is unlikely to induce a rapid decline of $\mathrm{N}$-CAM expression. This may not be surprising, since regenerating retinal axons go through a phase of exploratory growth (Schmidt et al. 1988; Stuermer, 
$1988 b)$ that is characterized by the emission and retraction of side-branches, and by the making and breaking of synaptic contacts. This process of remodelling lasts several months until the axons have assembled their terminal arbors at retinotopically appropriate sites and formed 'stable' synapses (Meyer et al. 1985; Stuermer, 1988a). Thus, not the initial phase of synaptogenesis, but the reformation of a map of near normal precision may correlate with a reduction in N-CAM expression. Accordingly, markedly fewer N-CAM-labeled axons were seen in the retinorecipient layers of the tectum at 250 days, none at 450 days (with the exception of those from the marginal retinal growth zone).

'Stable' connections may not be an adequate term to use in fish, since the contacts between the terminal arbors and the tectal cells are continuously broken and reformed at new sites. This process is known under 'shifting' of terminal arbors (Easter and Stuermer, 1984). Shifting is required for the maintenance of the retinotopic map during the ongoing, but geometrically different, growth patterns of the retina and the tectum (Gaze et al. 1979; Easter and Stuermer, 1984). Finescale synaptic remodelling during shifting apparently does not correlate with (and may not require) elevated levels of N-CAM expression on the retinal axons, as indicated by the absence of N-CAM immunofluorescence on the shifting axons.

That N-CAM may play an essential role for the process of map refinement during optic nerve regeneration in frogs has been proposed by Fraser et al. (1988). Anti-N-CAM released from agarose implants in the tectum was suggested to prevent map refinement in frogs. Whether regenerating axons in frog express, during map refinement, elevated levels of N-CAM as shown here for the regenerating axons in fish was not mentioned in the article by Fraser $e$ t al. (1988). N-CAM has also been implicated in the maintenance of synaptic contacts in adult frogs because anti-N-CAM causes a retraction of axons from the regions near the agarose implant releasing anti-N-CAM. Unfortunately, functional tests such as those by Fraser et al. (1988) cannot be performed with the Mab D3, since it binds to the intracellular domain of the N-CAM molecule (Schlosshauer, 1989).

$\mathrm{N}$-CAM (and $\mathrm{NgCAM}=\mathrm{L} 1$ ) has been implicated in neuron - glia interaction, since glial cells in vivo and in vitro express N-CAM (Bhat and Silberberg, 1988; Martini and Schachner, 1988). In the peripheral nervous system of the mouse, N-CAM (and NgCAM) is involved in neuron - Schwann cell adhesion and has been proposed to support axon outgrowth and possibly regeneration on Schwann cells (Seilheimer et al. 1989). Therefore, we sought to determine whether glial cells along the path of the growing and regenerating retinal axons in fish would be N-CAM-positive. As far as immunofluorescence on sections allows us to resolve, glial cell processes that partition the fiber bundles in the optic nerve, tract, and tectum did not exhibit N-CAM positive staining. However, whether the thin glial cell processes amongst the youngest retinal axons would be selectively N-CAM-positive is beyond the resolution of light microscopy. N-CAM immunoreactivity was also not detectable on glial cells among the regenerating axons, although the glial cells proliferate and increase in number in response to optic nerve injury (Giulian et al. 1985). Likewise glial cells in vitro cultured from the regenerating optic nerve and tract (Bastmeyer et al. $1989 b$ ), did not exhibit N-CAM immunoreactive sites. The cultured glial cells have proven to be highly growthpermissive for regenerating (N-CAM-positive) retinal axons in vitro (Stuermer, unpublished). Since N-CAM immunoreactivity is not detected on the glial cells in vitro but is present on the axons, we have no evidence for $\mathrm{N}$-CAM being important in the interactions between regenerating axons and glial cells in fish.

We wish to thank D. Edgar and E. Pollerberg for their comments and helpful corrections on the manuscript and acknowledge the generosity of E. Pollerberg, C. Goridis, G. Rougon, and F. Rathjen, who provided various antibodies.

\section{References}

Bastmeyer, M., Beckmann, M., Nona, S. M., Cronly-Dillon, J. R. ANd Stuermer, C. A. O. (1989b). Identification of astrocyteand oligodendrocyte-like cells of goldfish optic nerves in culture. Neutosci. Lett. 101, 127-132.

Bastmeyer, M., Schlosshauer, B. and Stuermer, C. A. O. (1989a). Expression of NCAM antigen in the goldfish retinotectal system. Soc. Neurosci. Abstr. 15, 574.

Bernhardt, R. AND EASTER, S. S., JR (1988). Regenerated optic fibers in goldfish reestablish a crude sectoral order in the visual pathway. J. comp. Neurol. 277, 403-419.

Bhat, S. AND Silberberg, D. H. (1988). Developmental expression of neural cell adhesion molecules of oligodendrocytes in vivo and in culture. J. Neurochem. 50, 1830-1838.

BradFord, M. M. (1976). A rapid and sensitive method for the quantitation of microgram quantities of protein utilizing the principle of protein-dye binding. Analyt. Biochem. 72, 248-254.

BuNT, S. M. (1982). Retinotopic and temporal organization of the optic nerve and tracts in the adult goldfish. J. comp. Neurol. 206, 209-226.

Chuong, C.-M. and Edelman, G. M. (1984). Alterations in neural cell adhesion molecules during development of different regions of the nervous system. J. Neurosci. 4, 2354-2368.

Cunningham, B. A., Hemperly, J. J., Murray, B. A., Prediger, E. A., Brackenbury, R. and Edelman, G. M. (1987). Neural cell adhesion molecule: Structure, immunoglobulin-like domains, cell surface modulation, and alternative RNA splicing. Science 236, 799-806.

Dodd, J., Morton, S. B., Karagogeos, D., Yamamoto, M. and JESSEL, T. M. (1988). Spatial regulation of axonal glycoprotein expression on subsets of embryonic spinal neurons. Neuron 1 , $105-116$.

Easter, S. S., Jr, Bratton, B. And Scherer, S. S. (1984). Growthrelated order of the retinal fiber layer in goldfish. $J$. Neurosci. 4 , 2173-2190.

Easter, S. S., Jr, Rusoff, A. C. And Kish, P. E. (1981). The growth and organization of the optic nerve and tract in juvenile and adult goldfish. J. Neurosci. 1, 793-811.

EAster, S. S., Jr, AND Stuermer, C. A. O. (1984). An evaluation of the hypothesis of shifting terminals in goldfish optic tectum. $J$. Neurosci. 4, 1052-1063.

Edelman, G. M. (1983). Cell adhesion molecules. Science 219, 450-457.

Fraser, S. E., Carhart, M. S., Murray, B. A., Chuong, C.-M. and Edelman, G. M. (1988). Alterations in the Xenopus retinotectal projection by antibodies to Xenopus NCAM. Devl Biol. 129, 217-230. 
GAZE, R. M. (1970). The Formation of Nerve Connections. Academic Press: London.

Gaze, R. M., Keating, M. J., Ostberg, A. and Chung, S. H. (1979). The relationship between retinal and tectal growth in larval Xenopus: Implications for the development of the retinotectal projection. J. Embryol. exp. Morph. 53, 103-143.

Giulian, D., Iwani, V. and Stuckenbrok, H. (1985). The response of optic tract glia during regeneration of the goldfish visual system. I. Biosynthetic activity within different glial populations after transection of retinal ganglion cell axons. Brain Res. 339, 87-96.

Harrelson, A. L. and Goodman, C. S. (1988). Growth cone guidance in insects: Fasciclin II is a member of the immunoglobulin superfamily. Science 242, 700-708.

Hawkes, R., Niday, E. ANd GoRdon, J. (1982). A dotimmunobinding assay for monoclonal and other antibodies. Analyt. Biochem. 119, 142-147.

Hirn, M., Pierres, M., Deagostini-Bazin, H., Hirsch, M. and GoRIDIS, C. (1981). Monoclonal antibody against cell surface glycoprotein of neurons. Brain Res. 214, 433-439.

Hoffman, S., Chuong, C.-M. and Edelman, G. M. (1984). Evolutionary conservation of key structures and binding functions of neural cell adhesion molecules. Proc. natn. Acad. Sci. USA 81, 6881-6885.

JACOBSON, M. (1988). Neural cell adhesion molecule (N-CAM). expression in Xenopus embryos during formation of central and peripheral neural maps. In The Making of the Nervous System (J. G. Parnavelas, C. D. Stern and R. V. Stırling, eds.) pp. 128-147. Oxford University Press: Oxford.

Jacobson, M. AND Rutishauser, U. (1986). Induction of neural cell adhesion molecule (NCAM) in Xenopus embryos. Devl Biol. $116,524-531$.

JohNs, P. R. (1977). Growth of the adult goldfish eye. III: Source of the new retinal cells. J. comp. Neurol. 176, 343-358.

Johns, P. R., Heacock, A. M. and Agranoff, B. W. (1978). Neurites in explant cultures of adult goldfish retina derived from ganglion cells. Brain Res. 142, 531-537.

LAEMmLI, U. K. (1970). Cleavage of structural proteins during the assembly of the head of bacteriophage T4. Nature, Lond. 227, 680-685.

Lowry, O. H., Rosebrough, N. J., Farr, A. L. and Randall, R. J. (1951). Protein measurement with the Folin phenol reagent. $J$. biol. Chem. 193, 265-275.

Martini, R. AND SCHACHNER, M. (1988). Immunoelectron microscopic localization of neural cell adhesion molecules (L1, N-CAM, and Myelin-associated glycoprotein) in regenerating adult mouse sciatic nerve. J. Cell Biol. 106, 1735-1746.

MEYER, R. L. (1978). Evidence from thymidine labeling for continuing growth of retina and tectum in juvenile goldfish. Expl Neurol. 59, 99-111.

Meyer, R. L., Sakurai, K and Schauwecker, E. (1985). Topography of regenerating optic fibers in goldfish traced with local wheat germ injections into retina: Evidence for discontinuous microtopography in the retinotectal projection. $J$. comp. Neurol. 239, 27-43.

Nona, S. M., Shehab, S. A. S., Stafford, C. A. and CronlyDILLON, J. R. (1989). Glial fibrillary acidic protein (GFAP). from goldfish: Its localisation in visual pathway. Glia 2, 189-200.

Pollerberg, E. G., Burridge, K., Krebs, K. E., Goodman, S. R. and SChachner, M. (1987). The $180-\mathrm{kD}$ component of the neural cell adhesion molecule N-CAM is involved in cell-cell contacts and cytoskeleton-membrane interactions. Cell Tiss. Res. 250, 227-236.

Pollerberg, E. G., Sadoul, R., Goridis, C. and Schachner, M. (1985). Selective expression of the $180-\mathrm{kD}$ component of the neural cell adhesion molecule N-CAM during development. $J$. Cell Biol. 101, 1921-1929.

Rankin, E. C. C. AND Cook, J. E. (1986). Topographic refinement of the regenerating retinotectal projection of the goldfish in standard laboratory conditions: A quantitative WGA-HRP study. Expl Brain Res. 63, 409-420.

Rathien, F. G. and Rutishauser, U. (1984). Comparison of two cell surface molecules involved in neural cell adhesion. EMBO J. 3, 461-465.

Rathien, F. G. and Schachner, M. (1984). Immunocytological and biochemical characterization of a new neuronal cell surface component ( $\mathrm{Ll}$ antigen) which is involved in cell adhesion. EMBO J. 3, 1-10.

Rathien, F. G., Wolff, J. M., Chang, S., Bonhoeffer, F. and RAPER, J. A. (1987). Neurofascin: a novel chick cell-surface glycoprotein involved in neurite-neurite interactions. Cell 51, 841-849.

Raymond, P. A. ANd EAster, S. S., JR (1983). Postembryonic growth of the optic tectum in goldfish. I. Location of germinal cells and numbers of neurons produced. J. Neurosci. $\mathbf{3}$, 1077-1091.

Rougon, G., Dubois, C., Buckley, N., Magnani, J. L. and ZOLLINGER, W. (1986). A monoclonal antibody against Meningococcus group B polysaccharides distinguishes embryonic from adult N.CAM. J. Cell Biol. 103, 2429-2437.

Rougon, G. and Marshak, D. (1986). Structural and immunological characterization of the amino-terminal domain of mammatian neural cell adhesion molecules. J. biol. Chem. 261, 3396-3401.

RUTISHAUSER, U. (1984). Developmental biology of a neural cell adhesion molecule. Nature, Lond. 310, 549-554.

RuTISHAUSER, U. (1986). Differential cell adhesion through spatial and temporal variations of NCAM. Trends Neurosci. 9, 374-378.

Schlosshauer, B. (1989). Purification of neuronal cell surface proteins and generation of epitope-specific monoclonal antibodies against cell adhesion molecules. J. Neurochem. 52, 82-92.

Schlosshauer, B., Schwarz, U. and Rutishauser, U. (1984). Topological distribution of different forms of neural cell adhesion molecule in the developing chick visual system. Nature, Lond. 310, 141-143.

Schmidt, J. T., Edwards, D. L. ANd Stuermer, C. A. O. (1983). The re-establishment of synaptic transmission by regenerating optic axons in goldfish: Time course and effects of blocking activity by intraocular injection of tetrodotoxin. Brain Res. 269, $15-27$.

Schmidt, J. T., Turcotte, J. C., Buzzard, M. and Tieman, D. G. (1988). Staining of regenerated optic arbors in goldfish tectum: Progressive changes in immature arbors and a comparison of mature regenerated arbors with normal arbors. J. comp. Neurol. 269, 565-591.

Seilheimer, B., Persohn, E. And Schachner, M. (1989). Neural cell adhesion molecule expression is regulated by Schwann cellneuron interactions in culture. J. Cell Biol. 108, 1909-1915.

Sharma, S. C., Braverman, S. B. and Rappaport, I. (1988). A monoclonal antibody specific for the visual system of the goldfish. Brain Res. 473, 359-364.

Stuermer, C. A. O. (1986). Pathways of regenerated retinotectal axons in goldfish. J. Embryol. exp. Morph. 93, 1-28.

Stuermer, C. A. O. (1988a). Trajectories of regenerating retinal axons in the goldfish tectum: I. A comparison of normal and regenerated axons at late regeneration stages. J. comp. Neurol. $267,55-68$.

Stuermer, C. A. O. (1988b). Trajectories of regenerating retinal axons in the goldfish tectum: Il. Exploratory branches and growth cones on axons at early regeneration stages. J. comp. Neurol. 267, 69-91.

Stuermer, C. A. O. AND EASter, S. S., Jr (1984a). Rules of order in the retinotectal fascicles of goldfish. J. Neurosci. 4, 1045-1051.

Stuermer, C. A. O. and Easter, S. S., Jr (1984b). A comparison of the normal and regenerated retinotectal pathways of goldfish. J. comp. Neurol. 223, 57-76.

Sunshine, J., Balak, K., Rutishauser, U. and Jacobson, M. (1987). Changes in neural cell adhesion molecule (NCAM) structure during vertebrate neural development. Proc. natn. Acad. Sci. U.S. A. 84, 5986-5990.

Towbin, H., Staehelin, T. and Gordon, J. (1979). Electrophoretic transfer of proteins from polyacrylamide gels to nitrocellulose sheets: procedure and some applications. Proc. natn. Acad. Sci. U.S. A. 76, 4350-4354. 
Vielmetter, J. ANd Stuermer, C. A. O. (1989a). Goldfish retinal axons respond to position-specific properties of tectal cell membranes in virro. Neuron 2, 1331-1339.

Vielmetter, J. AND Stuermer, C. A. O. (1989b). A monoclonal antibody which recognizes growing axons in the goldfish visual system. Soc. Neurosci. Abstr. 15, 1027.
Walter, J., Kern-Verts, B., Huf, J., Stolze, B. And BonHOEFFER, F. (1987). Recognition of position-specific properties of tectal cell membranes by retinal axons in vitro. Development 101, 685-696. 